\author{
EISSN:2706-7920 ISSN: 2077-4435 \\ DOI: $10.36632 / \mathrm{csi} / 2021.10 .3 .36$ \\ Journal homepage: www.curresweb.com \\ Pages: 414-424
}

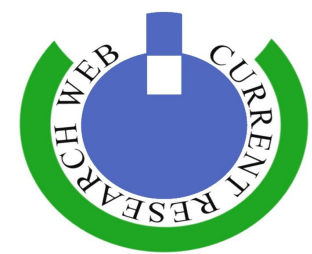

\title{
Radiometry Analysis of Alluvial Deposits Samples Collected from Sharm El-Sheikh Area, Southern Sinai. Egypt
}

\author{
Hanan A.S. Aly' ${ }^{1}$ N. I. Abd El Ghaffar ${ }^{2}$, Thanaa Abdel Maksod ${ }^{1}$ and A. I. M. Ismail ${ }^{2}$ \\ ${ }^{1}$ Physics Department, Faculty of Women for Arts, Science and Education, Ain Shams University, Egypt \\ ${ }^{2}$ Geological Sciences Department, National Research Centre, Cairo, Egypt

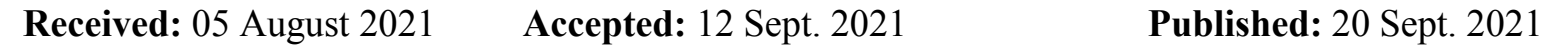

\begin{abstract}
At Sharm El-Sheikh area, alluvial deposits derived from younger granites which exhibit association of important minerals (alkali feldspar, plagioclase feldspar, quartz, allanite, zircon, monazite chevkinite and magnetite) were subjected to radiometry measurements using HP-Ge detector. Activity concentrations of the radionuclides were found to be near to each other except ${ }^{40} \mathrm{~K}$ which measure high values. Element content of thorium and uranium (eTh \& eU) was calculated to estimate uranium migration (in / out) process for the studied locality. Most of the studied samples were found belong to forbidden zone except samples Yg9 \& Yg10. The results indicated migration of uranium in percent ranges from $7.31 \%$ to $32.51 \%$ for the locality of the collected and studied samples. Detrital ${ }^{230} \mathrm{Th}$ was calculated to determine the corrected ${ }^{230} \mathrm{Th}_{\mathrm{d}}$ and applied to ${ }^{230} \mathrm{Th} /{ }^{234} \mathrm{U}$ dating which found to range between, 27 to $28 \mathrm{Ky}$. Migration time was also calculated using uranium original values.
\end{abstract}

Keywords: Alluvial deposits, Hp-Ge detector, Uranium dating, Uranium migration.

\section{Introduction}

In southern Sinai, granitic rocks are more predominant than any other area of the Arabian Nubian Shield (ANS), including $\sim 70 \%$ of the exposed basement complex (Bentor, 1985). The granitic rocks of the ANS comprise two main varieties: (1) older granites (620-820 My) involve Calc-alkaline I-type granitic rocks (quartz diorite- granodiorite) that were generated in orogenic volcanic arc tectonic regime (Hussein et al., 1982; Hassan and Hashad, 1990 \& Helal and Samir, 2008) and (2) younger granites (590-610 My) including highly fractionated Calc-alkaline I-type and alkaline A-type granites, and generated in post collisional tectonic setting of the shield creation (Hassan and Hashad, 1990; Beyth et al., 1994; Ali et al., 2009; Eyal et al., 2010 and Eyal et al., 2014).

The alluvial deposits (stream sediments) are the weathering products of various types of granitic rocks of younger granite types which is the dominant rock unit exposed in the studied area.

The granites are mainly composed of potash feldspar, plagioclase feldspar, quartz, mafic minerals (biotite + amphibole) and accessories (titanite, epidote, zircon, allanite, magnetite and opaques). These minerals are the main components of the alluvial deposits in the studied area.

It is well known that thorium, has opposed property to uranium which considered to be immobile in the weathering environment, on the other hand thorium undergo variation as a result of magnetic process more effective than uranium variations (Nash, 1979).

The primary sources of natural radioactivity in rock and soil are radionuclides of the elements uranium, thorium, and potassium (referred to as radioelements), specifically the uranium-238, thorium-232, decay chains and potassium- 40 .

Thorium is a naturally occurring, slightly radioactive element. It is found in small amounts in most rocks, where it is about three times abundant than uranium.Granitic rocks show a distinct increase over mafic igneous rocks, averaging 20-30 ppm. (Nash, 1979).

The transformation of neutral radioactive nuclei present in different types of rocks results in other radioactive isotopes as well, where the concentrations of the latter depend on the age of rocks as 
well as of their half-life. Radioactive equilibrium expected occurred between parents and their daughters for isolated types of rocks, but due to mobility of some isotopes rather than others causes disequilibrium and unequal activity concentrations will be observed. The present study, the content of thorium and uranium in the derived alluvial streaming sediments from various types of younger granitic rocks was investigated to estimate the age and uranium migration process occurred at the past time in the studied area.

\section{Geologic Setting}

The exposed Neoproterozoic basement complex of the studied area shown in Fig.1 is classified from oldest to youngest as follows: (Sherif et al., 2013) 1- Older granite (G 1) 2-Metavolcanics (Dokhan), and 3- younger granites of (G 2) (phase, II\& III= Alkali feldspar granite and III= Riebeckite granite), is the youngest rock unit in the studied area and intruded into the earlier phases GI and GII granites.

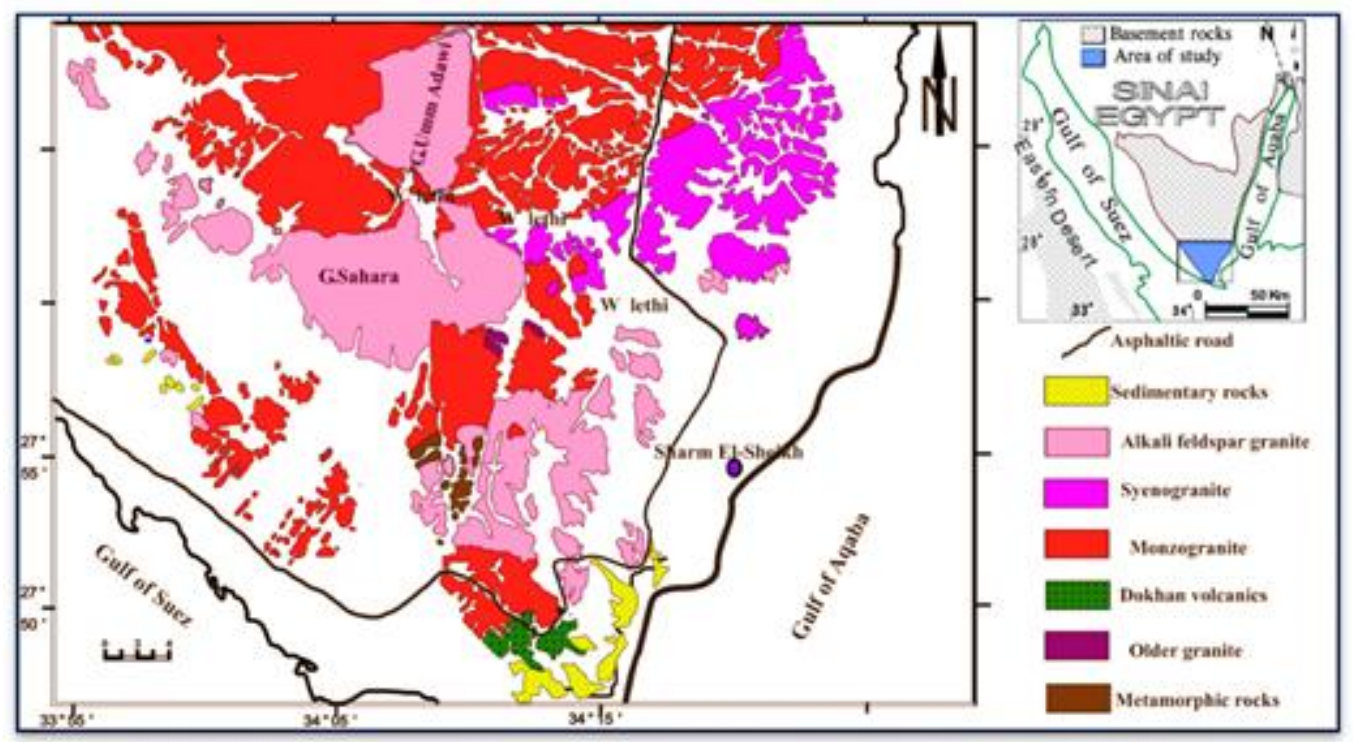

Fig. 1: Geologic map of the studied area.

Metavolcanics are rare in the studied area Fig. 2, they range in compositions from mafic to felsic. These volcanic rocks are effectiveness in alluvial deposits composition.

\section{Methodology}

\subsection{Sampling}

Dry stream sediments samples (alluvial deposits) were collected with interval of about $400 \mathrm{~m}$. The proper samples were picked at depth $30-50 \mathrm{~cm}$ with size fraction less than $1 \mathrm{~mm}$ and sample weight was about $20-25 \mathrm{Kg}$, each sample was quartered to reach a proper representative weight (1000 $\mathrm{gm})$. The collected fraction is a representative of dominant Precambrian granites outcropping in the studied area. Notes were taken at the sample site including location, any unusual sediment, and any indication of contamination and character of sediments. Fig. 2 is displaying the sample location map of the collected samples.

\subsection{HP-Ge detector and $\gamma$-ray spectrometry}

The samples were analysed non-destructively, using gamma-ray spectrometry with a high-purity germanium (HP- Ge) detector. This detector has a relative efficiency of approximately $50 \%$ of the 3 " $\mathrm{x}$ 3 " NaI (Tl) crystal efficiency, with a resolution of $1.90 \mathrm{keV}$ and a peak/Compton ratio of 69.9:1 at the $1.33 \mathrm{MeV}$ gamma-ray transition of ${ }^{60} \mathrm{Co}$. The detector is coupled to conventional electronics and connected to a multi-channel analyser (MCA) card installed in a personal computer (PC). The detector is shielded from the background radiation, using a $10-\mathrm{cm}$ thick lead shield, internally lined with a 2$\mathrm{mm}$ thick copper foil. The software program MAESTRO-32 was used to accumulate and analyse the data. The system is calibrated for energy to display gamma-ray photo-peaks between 63 and 3000 
$\mathrm{keV}$. The efficiency calibration was performed by using three well-known reference materials obtained from the International Atomic Energy Agency for the U, Th and $\mathrm{K}$ activity measurements: RGU-1, RGTh-1 and RGK-1, respectively (IAEA 1987, Anjos et al., 2005 \& El Aassy et al., 2011).

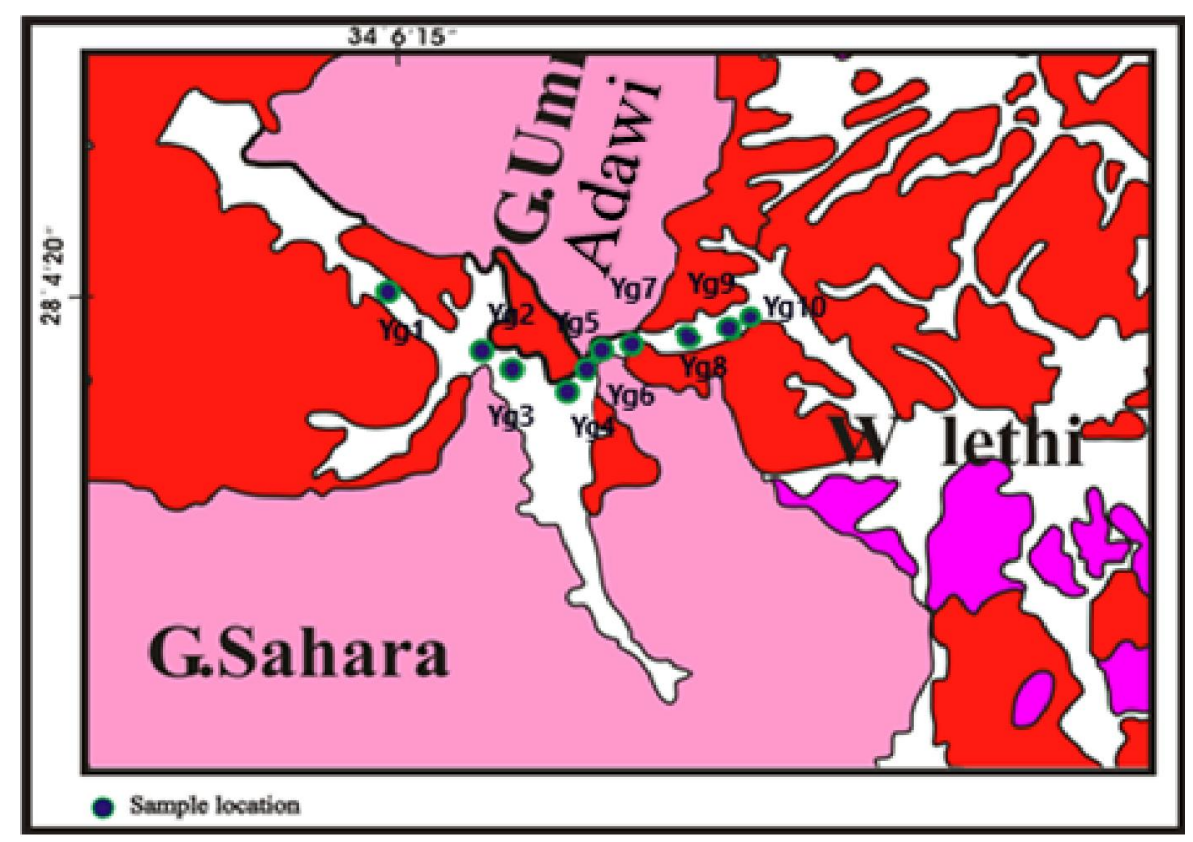

Fig. 2: Location map of the collected samples.

The uranium-238 activity was determined indirectly from analysing the gamma rays emitted by its daughter product $\left({ }^{234 \mathrm{~m}} \mathrm{~Pa}\right)$ determined from the $1001 \mathrm{keV}$ photo-peak, (Sutherland and deJong, 1990). The activity of $234 \mathrm{U}$ was determined from the gamma rays emitted by this nuclide at energy of $120.9(0.0342 \%) \mathrm{keV}$ (after the subtraction of the $120.35 \mathrm{keV}$ peak of $235 \mathrm{U})$, the uranium-235 activity was determined by its gamma ray photo-peaks: 143.8, 163.4, 185.7 and $205.3 \mathrm{keV}$ (Rameb"ack et al., 2010). The activity of 230Th was determined from the 67.7 (3.77\%) keV peak (Simpson, 1998). The specific activity of ${ }^{40} \mathrm{~K}$ was measured by its own gamma-ray emission at $1460.8 \mathrm{keV}$. The specific activity of ${ }^{226} \mathrm{Ra}$ was measured using the $186.1 \mathrm{keV}$ peak from its own gamma-ray emission (after the subtraction of the $185.7 \mathrm{keV}$ peak of ${ }^{235} \mathrm{U}$ ). The specific activity of ${ }^{214} \mathrm{~Pb}$ was measured using the 295.2 $\mathrm{keV}$ and $351.9 \mathrm{keV}$ peaks, whereas the specific activity of ${ }^{214} \mathrm{Bi}$ was measured using the $609.3 \mathrm{keV}$ peak. The specific activity of ${ }^{232} \mathrm{Th}$ was measured using the $338.4 \mathrm{keV}$ and $911.2 \mathrm{keV}$ peaks for ${ }^{228} \mathrm{Ac}$ and the $583 \mathrm{keV}$ and $2614.4 \mathrm{keV}$ peaks for ${ }^{208} \mathrm{Tl}$ (El Aassy et al., 2017).

\subsection{Gamma measurements}

The collected samples were crushed and ground to approximately $(60 \mu \mathrm{m})$ to obtain representative samples for performing the experiments and analyses. The samples were measured by $\gamma$-spectrometry using a hyper-pure germanium detector to determine the activity concentrations in units of $\mathrm{Bq} / \mathrm{kg}$ for ${ }^{238} \mathrm{U},{ }^{235} \mathrm{U},{ }^{226} \mathrm{Ra},{ }^{232} \mathrm{Th}$ and ${ }^{40} \mathrm{~K}$.

For the radiometric analysis, each dried sample was splattered by quartering, weighed and transferred to 200-ml capacity polyethylene Marinelli beaker, then sealed and stored for four to eight weeks to both prevent the escape of the radiogenic gases $\left({ }^{222} \mathrm{Rn}\right.$ and $\left.{ }^{220} \mathrm{Rn}\right)$ and to allow the attainment of radioactive equilibrium in the decay chain. After equilibrium has been reached among short lived isotopes and their progenies, the samples were subjected to gamma-ray spectrometric analysis. Each sample was measured during an accumulation time between $20 \mathrm{~h}$ and $24 \mathrm{~h}$. After the measurement of each sample, an empty cylindrical plastic container (polyethylene Marinelli beaker) was placed in the detection system for a counting period of $48 \mathrm{~h}$ to collect the background count rates. 


\subsection{Radioactivity counting}

The net area count after background corrections in each photo-peak was used in the computation of the activity concentration (C) in units of $\mathrm{Bq} \mathrm{kg}^{-1}$ for each of the radionuclides in the samples using the following expression, (Jibiri et al., 2007).

$\mathrm{C}\left(\mathrm{Bq} \mathrm{Kg}^{-1}\right)=\frac{C_{n}}{\varepsilon P_{\gamma} M_{S}}$

Where $\mathrm{C}_{\mathrm{n}}$ is the count rate under each photo-peak due to each radionuclide, $\varepsilon$ is the detector efficiency for the specific $\gamma$-ray, $\mathrm{P}_{\gamma}$ is the absolute transition probability of the specific $\gamma$-ray, and $\mathrm{M}_{\mathrm{s}}$ is the mass of the sample $(\mathrm{kg})$. The lowest limits of detection (LLD) were obtained from the relation (Jibiri and Bankole, 2006; Akram et al., 2006).

$\mathrm{LLD}=\frac{4.66 \mathrm{~S}_{\mathrm{b}}}{\varepsilon \times \mathrm{I}_{\gamma}}$

Where $S_{b}$ is the estimated standard error of the net background count rate in the spectrum of the radionuclide and $\mathrm{I} \gamma$ is the abundance of gamma emissions per radioactive decay. The LLD values obtained were $9.347,1.307$ and $1.344 \mathrm{~Bq} \mathrm{~kg}^{-1}$ for ${ }^{40} \mathrm{~K},{ }^{238} \mathrm{U}$ and ${ }^{232} \mathrm{Th}$, respectively.

Uranium migration in percent (Um \%) is given by (NMA, 1999).

$$
U m \%=\left(\frac{U m}{U p}\right) \times 100
$$

Where $\mathrm{U}_{\mathrm{P}}$ is the average measured $\mathrm{eU}$, and $\mathrm{Um}$ is given by:

$$
U m=U p-U o
$$

$\mathrm{U}_{\mathrm{o}}$ is given by:

$U o=\frac{e T h}{\text { regional }\left(\frac{e T h}{e U}\right)}$

The studied area is characterized by regional $\frac{e T h}{e U}=3.5 \sim 4$ (Mohammed et al., 2018).

\section{Results and Discussion}

\subsection{Microscopic identification of the source rock (granite) of the alluvial deposits}

Microscopically, the granites compose mainly of alkali feldspar (sanidine ( $\left.\mathrm{K} \mathrm{AlSi}_{3} \mathrm{O}_{8}\right)$ ), plagioclase feldspar minerals (albite $\left.\left(\mathrm{NaAlSi}_{3} \mathrm{O}_{8}\right)\right)$ or oligoclase $\left.\left((\mathrm{Na}, \mathrm{Ca}) \mathrm{AlSi}_{3} \mathrm{O}_{8}\right)\right)$ and quartz $\left(\mathrm{SiO}_{2}\right)$. In some cases, the rocks are composed of quartz, albite and microcline perthite, saussuritized oligoclase, riebeckite and biotite. The accessory phases include apatite $\left(\left(3 \mathrm{Ca}_{3}\left(\mathrm{PO}_{2}\right)_{2} \cdot \mathrm{CaF}_{2}\right)\right)$, Zircon $\mathrm{ZrSiO}_{4}$, Monazite $(\mathrm{Ce}, \mathrm{La}, \mathrm{Th}) \mathrm{PO}_{4}$, Thorite $\mathrm{ThSiO}_{4}$ and opaques which mainly represented by magnetite $\left(\mathrm{Fe}_{3} \mathrm{O}_{4}\right)$ as displayed in a group of Figs 3. A - D. 


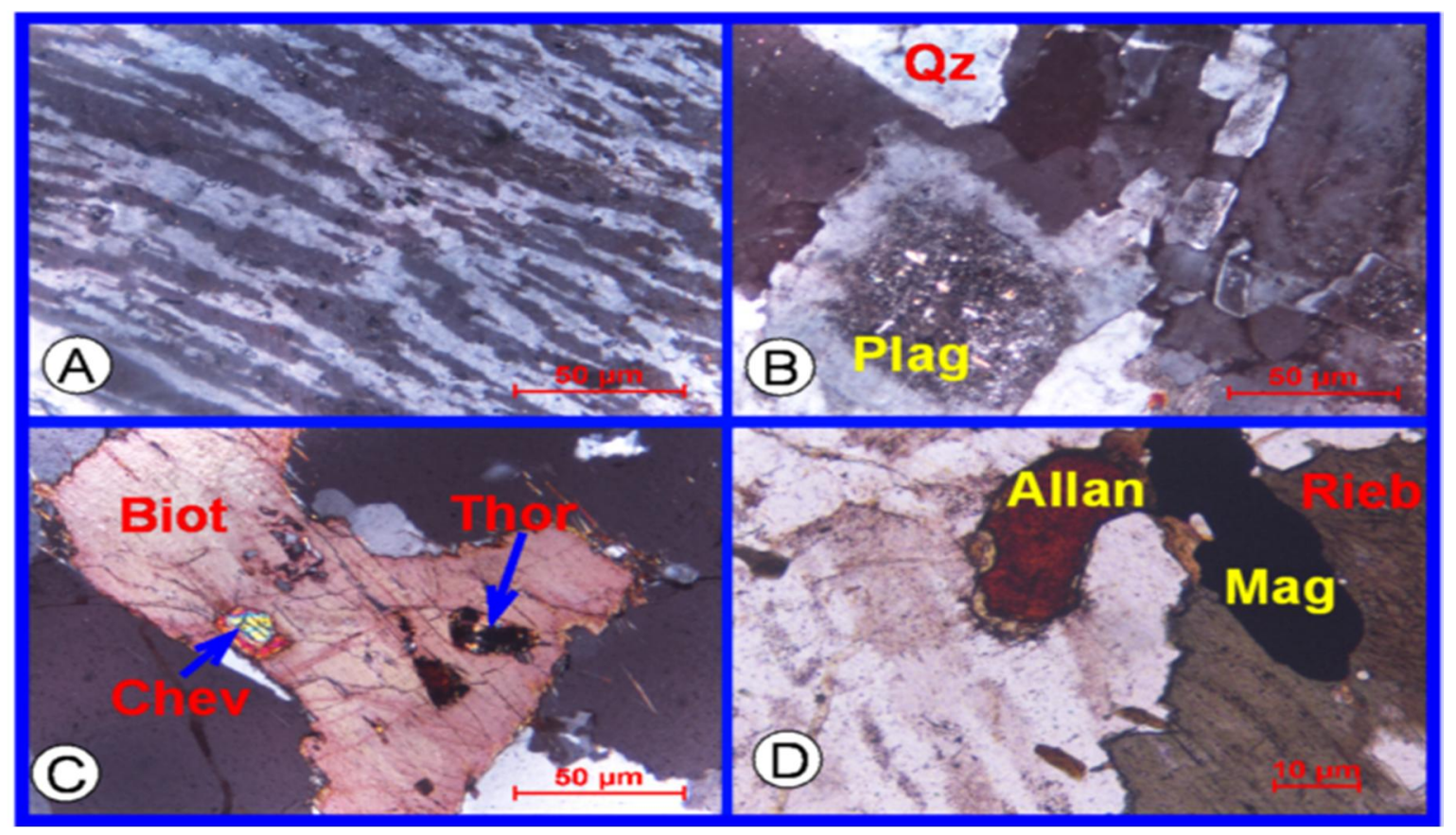

Fig. 3: (A) Large perthite crystal displaying veinlet type of perthitic intergrowth, (B) Association of quartz (Qz) crystals and plagioclase crystals (Plag), (C) Large subhedral biotite flake (Biot) enclosing fine crystals of chevkinite (Chev) and Thorite(Thor) and (D) Association of riebeckite (Rieb), allanite (Allan) and magnetite (Mag).

\subsection{Activity Concentrations}

The activity concentration values of different radionuclides ${ }^{238} \mathrm{U},{ }^{234} \mathrm{U},{ }^{230} \mathrm{Th}{ }^{226} \mathrm{Ra},{ }^{232} \mathrm{Th}$ and ${ }^{40} \mathrm{~K}$ in the ten samples were calculated using gamma counting and listed in Table 1. Activity concentrations shown in Table 1 are displayed in Figs. 4, 5, \&6 for different radionuclides.

Calculation of expected original values of uranium and the uranium migrated percent in the different samples were calculated using (equation.5) from equivalent uranium and thorium $\mathrm{eU} \& \mathrm{eTh}$ with uranium recorded in Table 2, activities ratios of ${ }^{234} \mathrm{U} /{ }^{238} \mathrm{U},{ }^{230} \mathrm{Th} /{ }^{234} \mathrm{U} \&{ }^{234} \mathrm{U} /{ }^{232} \mathrm{Th}$ were listed also in the same table.

As shown in Figs 4-7 activities of different radionuclides were near to each other except activity of ${ }^{40} \mathrm{~K}$ was found to be high and this is in agreement with characteristics of alluvial deposits, which being rich in potassium $(\mathrm{K})$ and abundant in most terrestrial and extra-terrestrial rocks (Cassata, 2012). Measured activity concentrations were recorded with lower values than other radionuclides for all studied alluvial deposits samples.

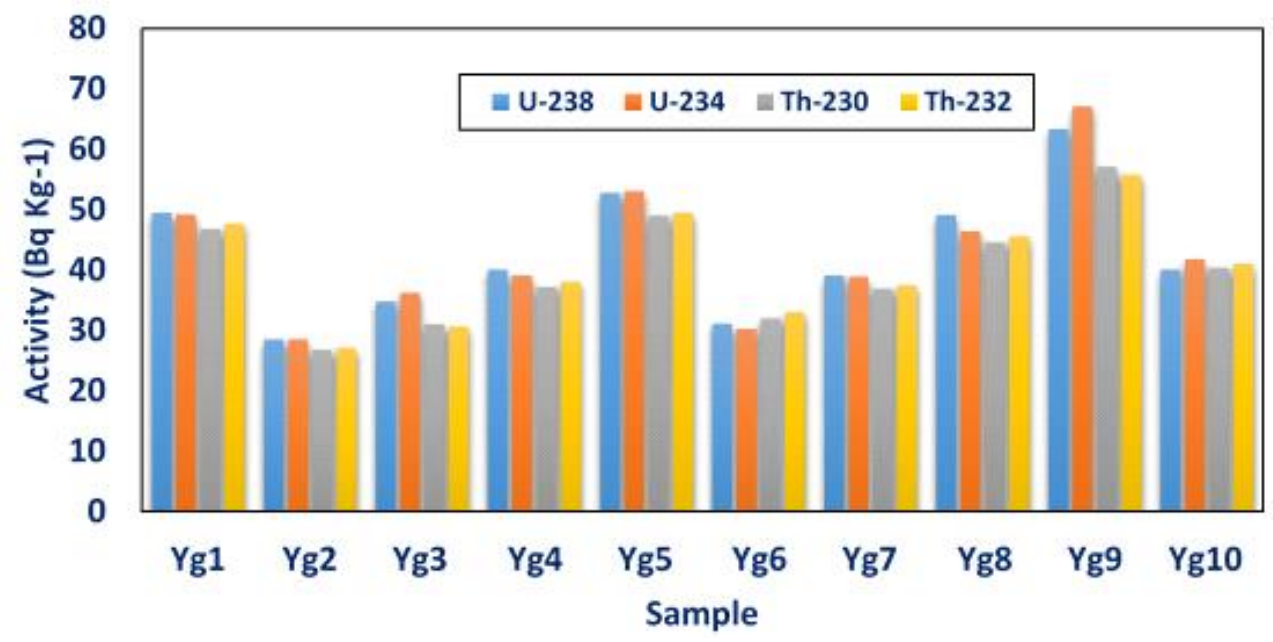

Fig. 4: The activity distributions of the $238 \mathrm{U}, 234 \mathrm{U}, 230 \mathrm{Th} \& 232 \mathrm{Th}$ radionuclides in the samples 
Table 1: Activity concentrations of different studied samples using gamma counting recorded by HP-Ge.

\begin{tabular}{clllllll}
\hline Sample & U-238 & U-234 & Th-230 & Ra-226 & Bi-214 & Pb-214 \\
\hline Yg1 & $49.47 \pm 2.03$ & $49.22 \pm 1.93$ & $46.81 \pm 2.10$ & $57.39 \pm 4.66$ & $56.75 \pm 4.92$ & $45.33 \pm 3.88$ & Th-232 \\
Yg2 & $28.52 \pm 5.26$ & $28.49 \pm 1.58$ & $26.81 \pm 1.45$ & $31.36 \pm 1.69$ & $31.98 \pm 1.84$ & $27.78 \pm 2.61$ & $27.13 \pm 3.04$ \\
Yg3 & $34.78 \pm 1.75$ & $36.21 \pm 2.33$ & $31.06 \pm 2.09$ & $46.49 \pm 3.47$ & $42.05 \pm 2.13$ & $42.42 \pm 3.44$ & $30.59 \pm 2.11$ \\
Yg4 & $40.05 \pm 8.31$ & $39.11 \pm 3.14$ & $37.17 \pm 3.71$ & $44.96 \pm 5.63$ & $43.19 \pm 3.08$ & $40.95 \pm 4.75$ & $38.05 \pm 4.26$ \\
Yg5 & $52.81 \pm 3.89$ & $53.07 \pm 4.06$ & $48.98 \pm 1.89$ & $58.20 \pm 4.77$ & $46.59 \pm 4.24$ & $42.77 \pm 2.86$ & $49.56 \pm 3.17$ \\
Yg6 & $31.17 \pm 5.26$ & $32.11 \pm 2.84$ & $32.01 \pm 2.37$ & $37.64 \pm 2.48$ & $36.23 \pm 2.33$ & $32.76 \pm 1.74$ & $33.01 \pm 2.04$ \\
Yg7 & $39.11 \pm 2.56$ & $38.92 \pm 1.88$ & $36.85 \pm 1.09$ & $44.21 \pm 3.75$ & $40.81 \pm 3.98$ & $42.77 \pm 4.06$ & $37.40 \pm 4.05$ \\
Yg8 & $49.19 \pm 1.23$ & $46.38 \pm 2.53$ & $44.60 \pm 1.25$ & $53.96 \pm 4.62$ & $48.04 \pm 4.55$ & $52.24 \pm 2.55$ & $45.53 \pm 5.22$ \\
Yg9 & $63.37 \pm 3.87$ & $67.12 \pm 4.40$ & $57.11 \pm 3.78$ & $69.84 \pm 5.81$ & $51.56 \pm 2.34$ & $49.18 \pm 4.10$ & $55.81 \pm 11.36$ \\
Yg10 & $40.05 \pm 2.09$ & $41.78 \pm 3.51$ & $40.39 \pm 2.15$ & $46.11 \pm 2.37$ & $41.38 \pm 3.06$ & $39.12 \pm 5.20$ & $41.04 \pm 4.88$ \\
\hline
\end{tabular}

Table 2: Eequivalent uranium and thorium ( eU \& eTh), uranium migration values $(\Delta \mathrm{U})$, uranium migration percent $(\Delta \mathrm{U} \%)$ and activities ratios for different studied samples

\begin{tabular}{|c|c|c|c|c|c|c|c|c|c|c|c|c|c|}
\hline \multirow[t]{2}{*}{ Sample } & \multirow[t]{2}{*}{ eU (ppm) } & \multirow[t]{2}{*}{ eTh (ppm) } & \multirow[t]{2}{*}{ e Th/e U } & \multicolumn{2}{|c|}{$\mathbf{U}_{0}$} & \multicolumn{2}{|c|}{$\Delta \mathrm{Um}(\mathrm{Bq} \mathrm{Kg}-1)$} & \multicolumn{2}{|c|}{$\Delta \mathrm{Um} \%$} & \multicolumn{4}{|c|}{ Activity Ratio } \\
\hline & & & & Max & Min & Min & $\operatorname{Max}$ & Min & Max & ${ }^{234} U /{ }^{238} U$ & ${ }^{230} \mathrm{Th} /{ }^{238} \mathrm{U}$ & ${ }^{234} \mathrm{U} /{ }^{232} \mathrm{Th}$ & ${ }^{230} \mathrm{Th} /{ }^{232} \mathrm{Th}$ \\
\hline Yg1 & 3.99 & 11.81 & 2.96 & 3.37 & 2.95 & 7.63 & 12.86 & 15.43 & 26.00 & 0.99 & 0.95 & 1.03 & 0.98 \\
\hline Yg2 & 2.30 & 6.72 & 2.92 & 1.92 & 1.68 & 4.73 & 7.70 & 16.58 & 27.01 & 1.00 & 0.94 & 1.05 & 0.99 \\
\hline Yg3 & 2.80 & 7.57 & 2.70 & 2.16 & 1.89 & 7.95 & 11.31 & 22.87 & 32.51 & 1.04 & 0.89 & 1.18 & 1.02 \\
\hline Yg4 & 3.23 & 9.42 & 2.92 & 2.69 & 2.35 & 6.68 & 10.85 & 16.68 & 27.10 & 0.98 & 0.93 & 1.03 & 0.98 \\
\hline Yg5 & 4.26 & 12.27 & 2.88 & 3.50 & 3.07 & 9.35 & 14.78 & 17.70 & 27.99 & 1.00 & 0.93 & 1.07 & 0.99 \\
\hline Yg6 & 2.51 & 8.17 & 3.25 & 2.33 & 2.04 & 2.22 & 5.84 & 7.13 & 18.74 & 0.97 & 1.03 & 0.92 & 0.97 \\
\hline Yg7 & 3.15 & 9.26 & 2.94 & 2.64 & 2.31 & 6.31 & 10.41 & 16.14 & 26.62 & 1.00 & 0.94 & 1.04 & 0.99 \\
\hline Yg8 & 3.97 & 11.27 & 2.84 & 3.22 & 2.82 & 9.26 & 14.25 & 18.83 & 28.97 & 0.94 & 0.91 & 1.02 & 0.98 \\
\hline Yg9 & 5.11 & 13.81 & 2.70 & 3.95 & 3.45 & 14.43 & 20.55 & 22.77 & 32.42 & 1.06 & 0.90 & 1.20 & 1.02 \\
\hline Yg10 & 3.23 & 10.16 & 3.15 & 2.90 & 2.54 & 4.06 & 8.56 & 10.14 & 21.37 & 1.04 & 1.01 & 1.02 & 0.98 \\
\hline
\end{tabular}




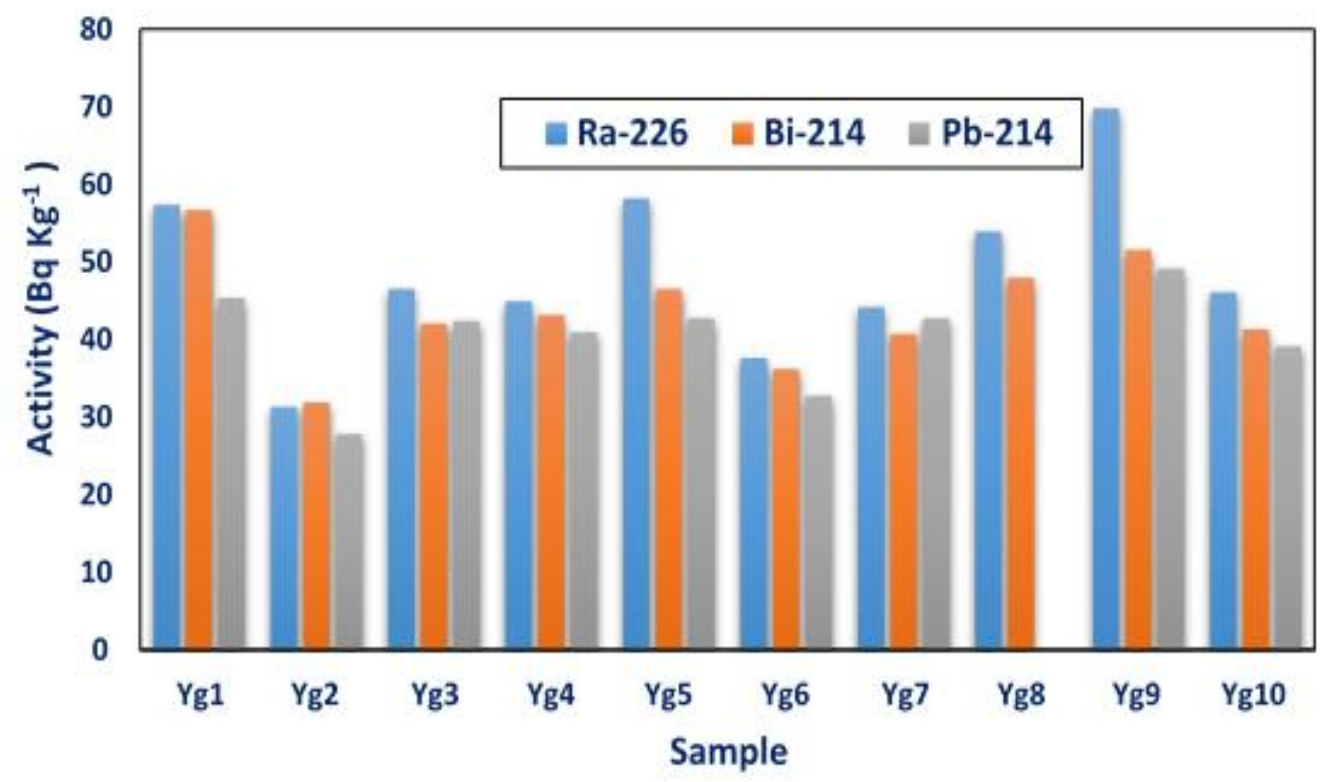

Fig. 5: The activity distribution of the 226Ra, 214Bi \& $214 \mathrm{~Pb}$ radionuclides in the samples.

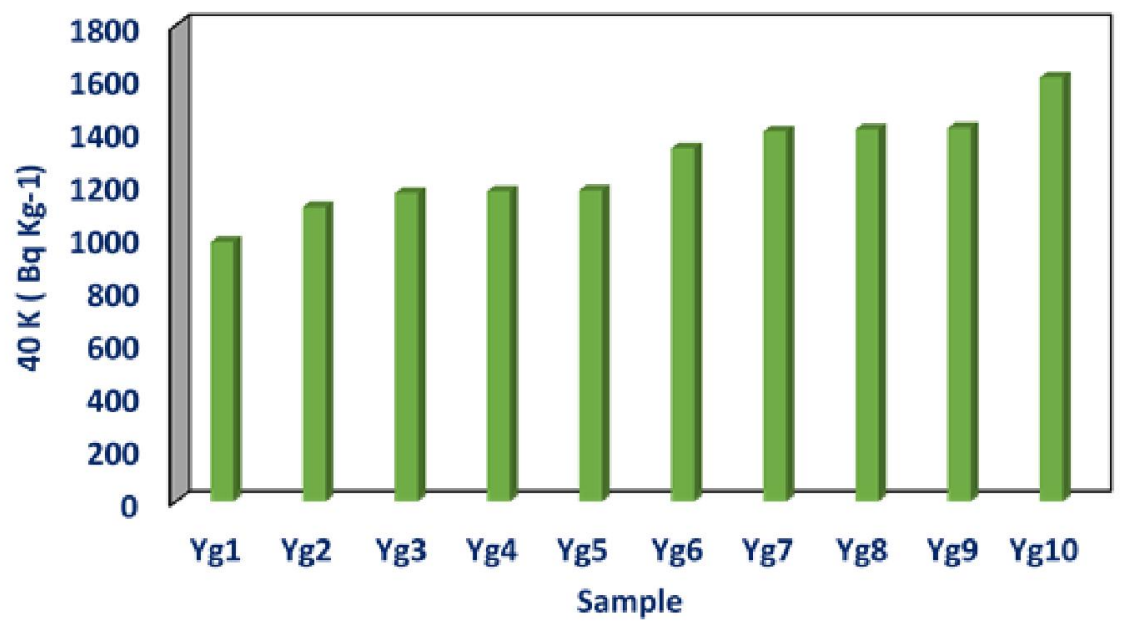

Fig. 6: The activity concentration of the ${ }^{40} \mathrm{~K}$ in the samples

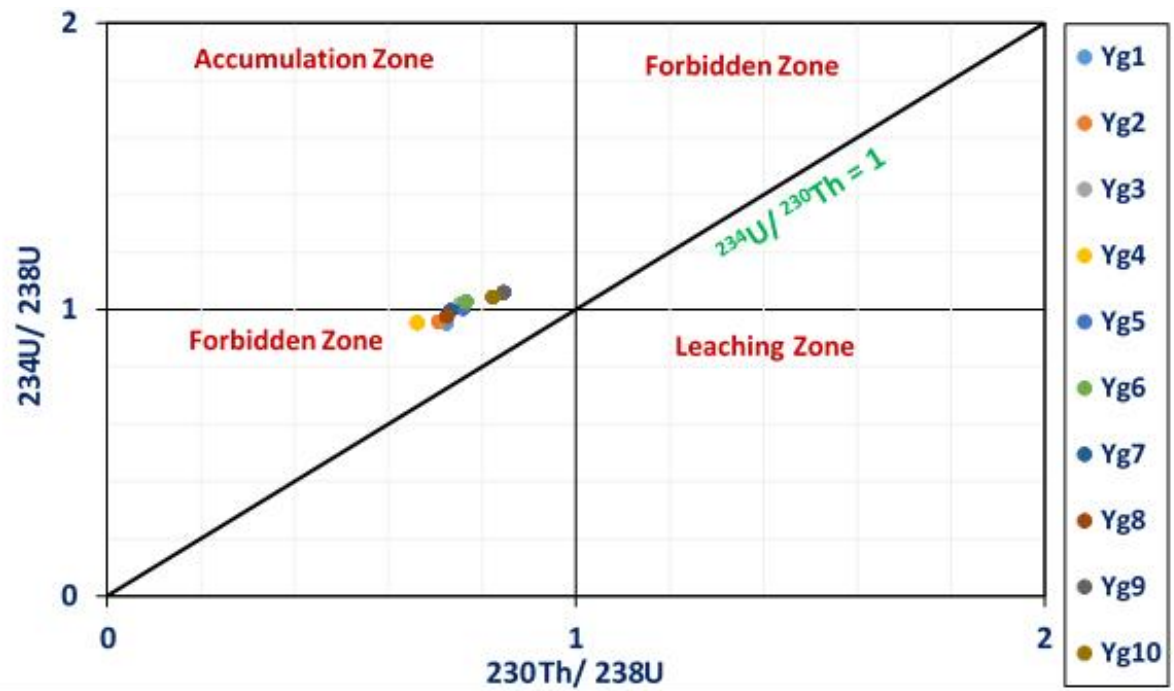

Fig. 7: Thiel diagram of ${ }^{230} \mathrm{Th} /{ }^{238} \mathrm{U}{ }^{234} \mathrm{U} /{ }^{238} \mathrm{U}$. Most of samples located at forbidden zone and its boundary. 


\subsection{Uranium Migration}

Radiometric determinations of element content for uranium (eU) and thorium (eTh) for different samples were listed in Table 2. Calculation of original maximum and minimum uranium values corresponding to migration percent has been take place using equation .3. Uranium migration occurred to the studied locality, ranges from 2.22 to $20.55 \mathrm{BqKg}^{-1}$ and the migration percent ranges from 7.13 $\%$ to $32.51 \%$. Maximum uranium migration percent was found at sample Yg3 which is the sample mostly exposed to water stream, and this causes the uranium leaching from the surrounding and precipitated in this sample, while the minimum uranium migration percent was found at sample Yg6 which is the most distant sample from exposure to water stream with less chance to transported leached uranium.

\subsection{Activity Ratios}

Measurements setting of activity concentrations by gamma counting help to keep secular equilibrium among ${ }^{238} \mathrm{U}$, and its progenies, if it was present in the original collected sample. The relations of the activity ratios between ${ }^{234} \mathrm{U} /{ }^{238} \mathrm{U},{ }^{230} \mathrm{Th} /{ }^{238} \mathrm{U},{ }^{234} \mathrm{U} /{ }^{232} \mathrm{Th}$ and ${ }^{230} \mathrm{Th} /{ }^{232} \mathrm{Th}$ are listed in Table 2 and displayed in Fig. 7 which represents Thiel diagram to determine the nature of locality of selected studied alluvial deposits samples (Thiel et al., 1983). Most of studied samples belong to forbidden zone and near this zone boundary except samples Yg9 \& Yg10 within the accumulation zone, these samples are exposed to dense water current.

\subsection{Time of Alteration}

The time of alteration was calculated using equation 6 (Samer et al., 2015):

${ }^{234} \mathrm{U} /{ }^{238} \mathrm{U}$ activity ratio is nearly equal 1 for all the studied samples which satisfying condition for using equation. 6 after rearrangement as the following formulae:

$$
\frac{230 T h}{234 U}=\left(1-e^{\lambda_{230} t}\right)
$$

To give equation.7:

$$
t=-\lambda_{230}^{-1} \ln \left(1-\frac{230 T h}{234 \mathrm{U}}\right)
$$

Thorium indicated in Equation.6 is radiogenic ${ }^{230} \mathrm{Th}$ as decay product of ${ }^{234} \mathrm{U}$ so it should be first calculate the detrital ${ }^{230} \mathrm{Th}_{\mathrm{d}}$ such that the measured total thorium

${ }^{230} \mathrm{Th}_{\mathrm{t}}={ }^{230} \mathrm{Th}+{ }^{230} \mathrm{Th}_{\mathrm{d}}{ }^{230} \mathrm{Th}_{\mathrm{d}}$ was calculated from the relation of ${ }^{230} \mathrm{Th} /{ }^{232} \mathrm{Th} \&{ }^{234} \mathrm{U} /{ }^{232} \mathrm{Th}$ activities ratios, as the $\mathrm{Y}$ intersection at ${ }^{234} \mathrm{U}$ activity equal zero (Kaufman et al., 1965\& Mebus, 2001).

Equation.8 represent the formulae of line shown in Fig. 8:

$$
\frac{230 \mathrm{Th}}{232 \mathrm{Th}}=0.23 \frac{234 \mathrm{U}}{232 \mathrm{Th}}+0.75
$$

The time of alteration processes for different samples was calculated from equation. 7 using the corrected ${ }^{230} \mathrm{Th}$ after subtraction the ${ }^{230} \mathrm{Th}_{\mathrm{d}}$ as listed in Table 3 . Time of migration has been calculated and recorded in Table 4

Migration time has good correlation with ${ }^{234} \mathrm{U}$ as shown in Fig. 9 current activity, such that the activity of ${ }^{234} \mathrm{U}$ is growing up by time as ${ }^{238} \mathrm{U}$ decayed. 
Table 3: Time of alteration for the studied samples using corrected ${ }^{230} \mathrm{Th}$.

\begin{tabular}{|c|c|c|c|c|c|}
\hline Sample & ${ }^{230}$ Thd & ${ }^{230} \mathrm{Th}$ (corrected) & ${ }^{230} \mathrm{Th} /{ }^{234} \mathrm{U}$ & ${ }^{230} \mathrm{Th} /{ }^{234} \mathrm{U}$ & Age (Ky) \\
\hline Yg1 & 35.783 & 11.0275 & 0.224 & 0.776 & 27.60 \\
\hline Yg2 & 20.348 & 6.4625 & 0.227 & 0.773 & 27.99 \\
\hline Yg3 & 22.943 & 8.1175 & 0.224 & 0.776 & 27.62 \\
\hline Yg4 & 28.538 & 8.6325 & 0.221 & 0.779 & 27.13 \\
\hline Yg5 & 37.170 & 11.8100 & 0.223 & 0.777 & 27.39 \\
\hline Yg6 & 24.758 & 7.2525 & 0.226 & 0.774 & 27.85 \\
\hline Yg7 & 28.050 & 8.8000 & 0.226 & 0.774 & 27.89 \\
\hline Yg8 & 34.148 & 10.4525 & 0.225 & 0.775 & 27.78 \\
\hline Yg9 & 41.858 & 15.2525 & 0.227 & 0.773 & 28.05 \\
\hline Yg10 & 30.780 & 9.6100 & 0.230 & 0.770 & 28.44 \\
\hline
\end{tabular}

Table 4: Time of migration for the studied samples using originated ${ }^{234} \mathrm{U}$.

\begin{tabular}{cccccccc}
\hline \multirow{2}{*}{ Sample } & \multirow{2}{*}{${ }^{230} \mathbf{T h} /{ }^{234} \mathbf{U}$} & \multirow{2}{*}{ Age (Ky) } & \multicolumn{2}{c}{${ }^{234} \mathbf{U}$ (migrated) } & \multicolumn{3}{c}{ Age (Ky) (migrated) } \\
\cline { 3 - 7 } & & & Max. & Min. & Max. & Min. & Average \\
\hline Yg1 & 0.224 & 27.60 & 45.85 & 46.27 & 109.19 & 109.76 & 109.47 \\
Yg2 & 0.227 & 27.99 & 26.57 & 26.81 & 127.26 & 127.99 & 127.62 \\
Yg3 & 0.224 & 27.62 & 34.05 & 34.32 & 121.94 & 122.53 & 122.24 \\
Yg4 & 0.221 & 27.13 & 36.42 & 36.76 & 120.21 & 120.87 & 120.54 \\
Yg5 & 0.223 & 27.39 & 49.57 & 50.00 & 106.49 & 107.01 & 106.75 \\
Yg6 & 0.226 & 27.85 & 29.78 & 30.07 & 123.89 & 124.66 & 124.27 \\
Yg7 & 0.226 & 27.89 & 36.28 & 36.61 & 117.83 & 118.49 & 118.16 \\
Yg8 & 0.225 & 27.78 & 43.16 & 43.56 & 111.13 & 111.74 & 111.43 \\
Yg9 & 0.227 & 28.05 & 63.17 & 63.67 & 91.45 & 91.80 & 91.63 \\
Yg10 & 0.230 & 28.44 & 38.88 & 39.24 & 113.19 & 113.83 & 113.51 \\
\hline
\end{tabular}

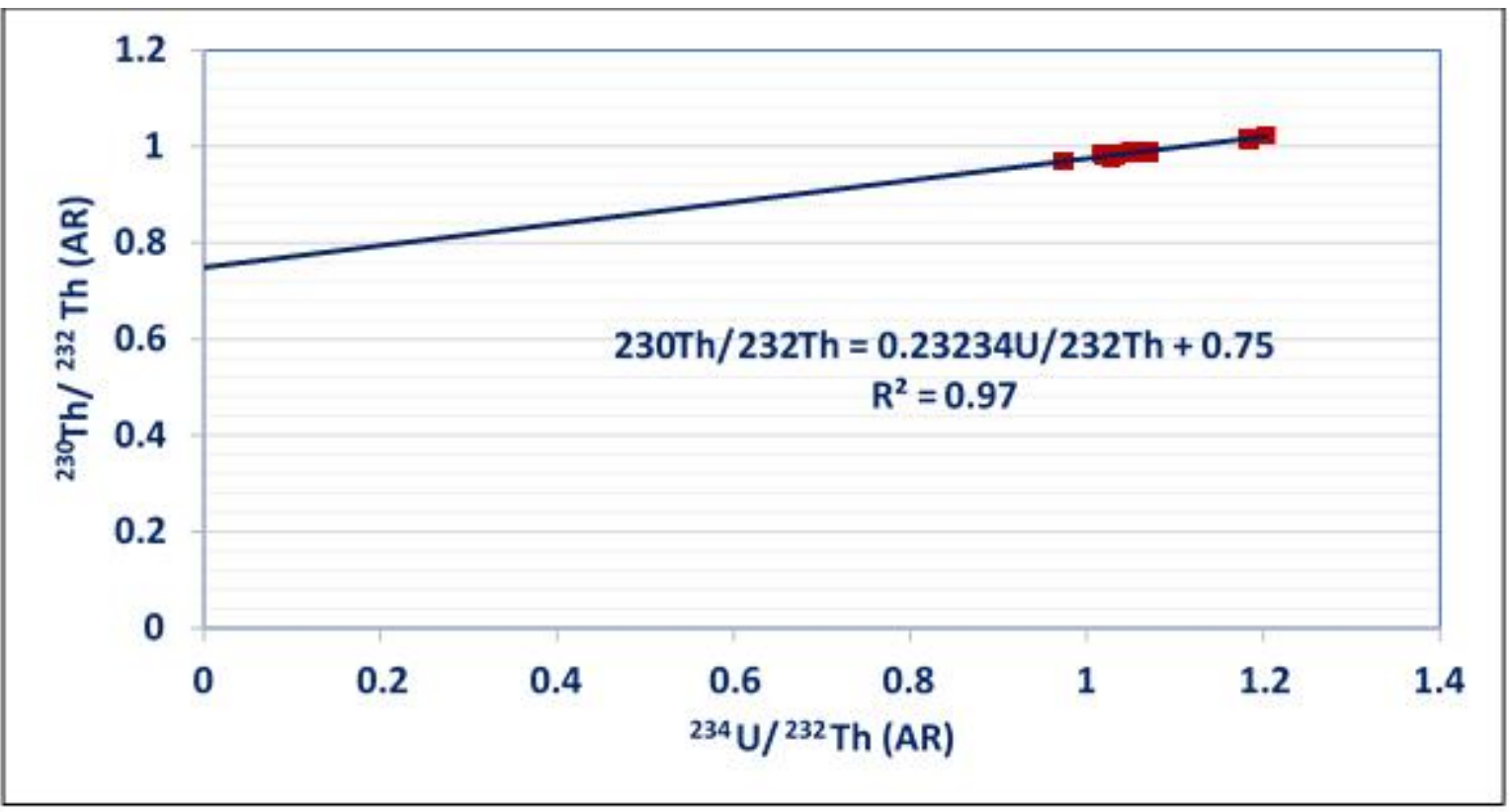

Fig. 8: ${ }^{230} \mathrm{Th} /{ }^{232} \mathrm{Th}$ vs ${ }^{234} \mathrm{U} /{ }^{232} \mathrm{Th}$ curve to deduce corrected ${ }^{230} \mathrm{Th}$. 


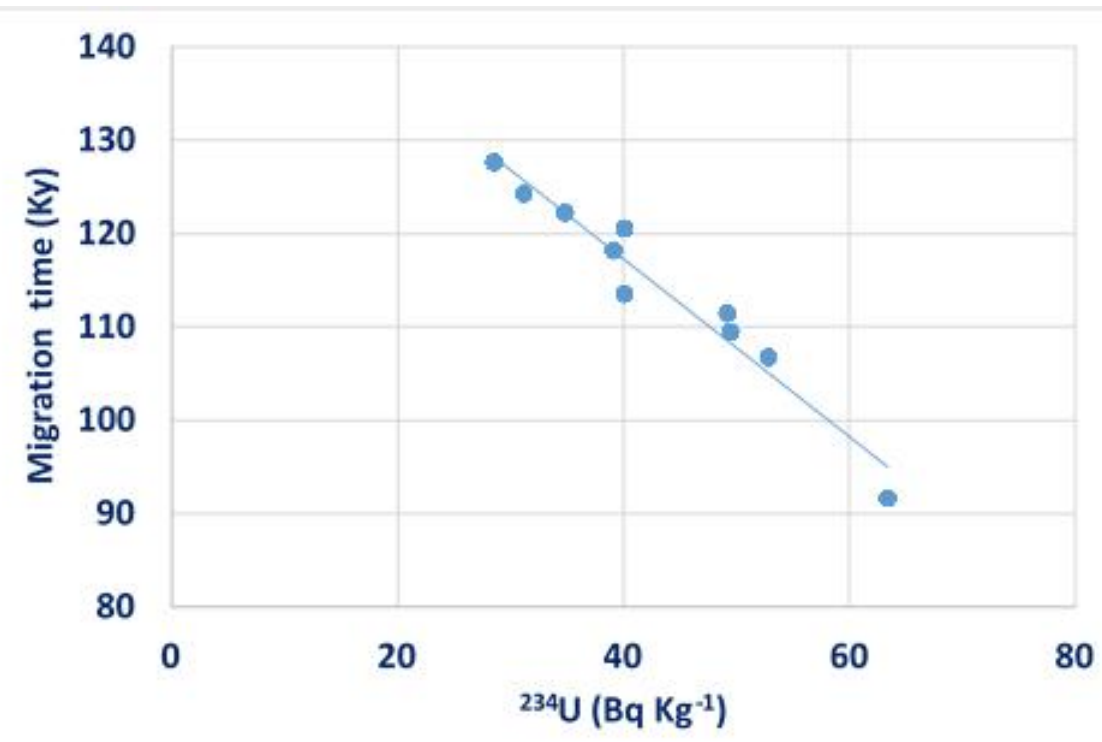

Fig. 9: Time of migration vs. ${ }^{234} \mathrm{U}$ activity $\left(\mathrm{Bq} \mathrm{Kg}{ }^{-1}\right)$ for different studied samples.

\section{Conclusions}

In the present study, microscopic identification of the source rocks and radioactivity levels of radionuclides were determined using gamma-ray spectrometer with high purity germanium detector. Moreover, the determination uranium migration values and percent for each of the studied samples, to obtain the migration percent which was found to be migration in process. The obtained results show maximum activity for ${ }^{40} \mathrm{~K}$; the activity concentration values of ${ }^{238} \mathrm{U} \&{ }^{232} \mathrm{Th}$ and their progeny were detected in all samples but lower than ${ }^{40} \mathrm{~K}$. Low activity of uranium and its progeny for the selected studied samples was observed, therefore it is safe to uses as row material in industry.

Time of alteration processes within the studied samples was calculated results shows the average of this time ranges from 27 to $28 \mathrm{Ky}$. Time intervals within which the uranium migration occurred has been calculated by using original values of uranium.

\section{References}

Akram, M., M. Riffat, N.A. Qureshi, and J.S. Tariq, 2006. Determination of gamma- emitting radionuclides in the inter-tidal sediments off Balochistan (Pakistan) coast, Arabian Sea, Radiat. Prot. Dosim., 105: 1-6.

Ali, B.H., S.A. Wilde, and M.M.A. Gabr, 2009. Granitoid evolution in Sinai, Egypt, based on precise SHRIMP U-Pb ziron geochronology. Gondwana Res., 15: 38-48.

Anjos, R.M., R. Veiga, T. Soares, A.M.A. Santos, J.G. Aguiar, M.H.B.O. Frasca, Y.K. Bentor, 1985. The crust evolution of the Arabo-Nubian Massif with special reference to the Sinai Peninsula. Precamb. Res., 2: 1-74.

Beyth, M., R.J. Stern, R. Altherr, and A. Kröner, 1994. The late Precambrian Timna igneous complex, Southern Israel: Evidence for comagmatic-type sanukitoid monzodiorite and alkali granite magma. Lithos., 31: 103-124.

Brage, J.A.P., D. Uz^eda, L. Mangia, A. Facure, B. Mosquera, C. Carvalho, and P.R.S. Gomes, 2005. "Natural radionuclide distribution in Brazilian commercial granites". Radiat.Meas., 39:245-253.

Cassata,W., 2012: Systematic variations in argon diffusion in alluvial depositss: Constraints on diffusion length scales, diffusive anisotropy, and non-linear Arrhenius arrays and implications for noble gas thermo-chronometry, Ph.D Thesis, University of California, Berkeley. Available at: https://escholarship.org/uc/item/381302kj.

El Aassy, I.E., M.M. El Galy, A.A. Nada, M.G. El Feky, T.M. Abd El Maksoud, S.M. Talaat, and E.M. Ibrahim, 2011. Effect of alteration processes on the distribution of radionuclides in uraniferous sedimentary rocks and their environmental impact, south-western Sinai, Egypt. J. Radioanal. Nucl. Chem., 289: 173-184. 
El Aassy, I.E., M.G. El Feky, M.A. El Kasaby, E.M. Ibrahim, S. Sewef, and R.M. Attia, 2017. Behavior of radionuclides during acidic leaching processes of different rock materials, Allouga locality, south-western Sinai, Egypt. Int. J. Sci. Eng. Res., 8:1135-1147.

Eyal, M., Y. Be'eri-Shlevin, Y. Eyal, M.J. Whitehouse, and B. Litvinovsky, 2014. Three successive Proterozoic island arcs in the northern Arabian- Nubian Shield: evidence from SIMS U-Pb dating of zircon. Gondwana Res., 25: 338-351.

Eyal, M., B. Litvinovsky, B.M. Jahn, A. Zanvilevich, and Y. Katzir, 2010. Origin and evolution of post-collisional magmatism: coeval neoproterozoic calcalkaline and alkaline suites of the Sinai Peninsula. Chem. Geol., 269: 153-179.

Hassan, M.A. and A.H. Hashad, 1990. Precambrian of Egypt. In: Said, R (Ed.), The geology of Egypt. Balkema, Rotterdam, 201-245.

Helal, R.M. and M.A.E. Samir, 2008. Comparative response of drought tolerant and drought sensitive maize genotypes to water stress, Australian Journal of Crop Science, 1:31-36.

Hussein, A.A., M.A. Monir, and F.E. Mohamed, 1982. A proposed new classification of the granites of Egypt, Journal of Volcanology and Geothermal Research, 14: 187-198.

IAEA, 1987. Preparation and Certification of IAEA Gamma Spectrometry Reference Materials, RGU1, RGTh-1 and RGK-1. International Atomic Energy Agency. Report-IAEA/RL/148.

Jibiri, N.N., and S.O. Bankole, 2006. Soil radioactivity and radiation absorbed dose rates at roadsides in high-traffic density areas in Ibadan Metropolis, southwestern Nigeria. Radiat. Prot. Dosimetry, 118: 453-458.

Jibiri, N.N., P.I. Farai, and K.S. Alausa, 2007. "Estimation of annual effective dose due to natural radioactive elements in ingestion of foodstuffs in tin mining area of Jos-Plateau, Nigeria". J. Environ. Radiat., 94: 31-40.

Kaufman A. and W.S. Broecker, 1965. Comparison of Th230 and C14 ages for carbonate materials from lakes Lahontan and Bonneville. Journal of Geophysical Research Vol. 70: 4039-4054.

Mebus, A.G., 2001. Reflection On The $230 \mathrm{Th} / \mathrm{U}$ Dating Of Dirty Material, Journal on Methods and Applications of Absolute Chronology, 20: 9-14.

Mohammed, Z.E., and E.S. Ahmed, 2018. Geochemistry, petrogenesis and radioactive mineralization of two coeval Neoproterozoic post-collisional calc-alkaline and alkaline granitoid suites from Sinai, Arabian Nubian Shield, journal of Geochemistry "Chemie der Erde"., 78: 15-39.

Nash, J.T., 1979: Uranium and thorium in granitic rocks of north-eastern Washington and northern Idaho, with comments on uranium resource potential, Open-File Report, United States Department of the Interior Geological Survey. 79-233.

NMA. Nuclear Materials Authority, Internal Scientific Report, 1999. Study of Abu Zinima Area, South Sinai, Egypt.

Ramebäck, H., A. Vesterlund, A. Tovedal, U. Nygren, L. Wallberg, E. Holm, C. Ekberg, and G. Skarnemark, 2010. "The Jackknife as an Approach for Uncertainty Assessment in Gamma Spectrometric Measurements of Uranium Isotope Ratios. Nuclear Instruments and Methods in Physics Research B: Beam Interactions with Materials and Atoms., 268: 2535-2538.

Samer, F., Z. Abdallah, A. Jalal, F. Samir, I. Hanadi, E. Ahmad, B. Mirvat, H. Nafez, H. Katia, and Z. Zaher, 2015: New Concept For Calculating The Age Of A Fossil Bone By Uranium-Series Method, International Journal of Scientific \& Technology Research, 4: 8-14.

Simpson, J.J., and R. Grün, 1998. Non-destructive gamma spectrometric U-series dating. Quat Geochronol, 17: 1009-1022.

Sherif, M., M. Ghoneim, M. Heikal, and B. El Dosuky, 2013. Perogenesis of granites, Sharm ElSheikh area, South Sinai, Egypt: petrological constrains and tectonic evolution. Miner Petrol, 107:765-783.

Sutherland, R.A. and E. de Jong, 1990. Statistical analysis of gamma-emitting radionuclide concentrations for three fields in southern Saskatchewan, Canada. Health Phys., 58: 417-428.

Thiel, K., R. Vorwerk, R. Saager, and H. Stupp, 1983:235U fission tracks and 238U-series disequilibria as a means to study recent mobilization of uranium in Archaean pyretic conglomerates. Earth Planet. Sci. Lett., 65: 249-262. 